\title{
The Relationship between Iranian EFL Teachers' Critical Thinking Ability and their Professional Success
}

\author{
Parviz Birjandi \& Marzieh Bagherkazemi \\ Allameh Tabataba'i University, Tehran, Iran \\ Tel: 98-221-523-6225_E-mail:m_bk43@yahoo.com
}

\begin{abstract}
In the face of too much incoming information and too many people trying to convince us in today's world, the ability to think critically gains an ever greater saliency as a prime goal of student and teacher education. The present study aimed at substantiating the relationship between EFL teachers' critical thinking ability and their student-evaluated professional success. To this end, measures of the critical thinking ability of 67 Iranian EFL teachers were obtained using the Farsi version of Watson-Glaser Critical Thinking Appraisal, Form A (WGCTA-FA) (Watson \& Glaser, 1980) (Faravani, 2006). In addition, their professional success was estimated by their students through the Successful Iranian EFL Teacher Questionnaire (SIETQ) (Pishghadam \& Moafian, 2009). The Pearson product-moment correlation analysis indicated a statistically significant relationship between the two sets of measures $(r=0.7, p \leq 0.05)$. More specifically, the multiple regression analysis demonstrated that three of the five aspects of critical thinking as defined by Watson and Glaser (1980), namely 'drawing inferences', 'interpreting evidence' and 'evaluating arguments', are significantly positively correlated with SIET scores. Implications relate to the need to accommodate 'critical thinking' as an essential aspect of EFL teacher education and teacher evaluation programs, and to readdress the concept of EFL/ESL teacher effectiveness with an eye to teachers' critical thinking ability.
\end{abstract}

Keywords: Critical Thinking, Teacher Success, Multiple regression

\section{Introduction}

It goes without saying that teachers are an ultimate key, if not the key, to successful education and that they play a vital role in bringing about educational reform (Hargreaves \& Fullan, 1992; Suwandee, 1995). This is true of education in general and language education in particular. Therefore, it is not surprising that an extensive range of language education research has addressed the characteristic features of successful language teachers, and the ways language teacher education programs can induce the enhancement of such features.

Some of these studies have sought to yield a broader conception of teacher success than one which only accords significance to professional qualities as language proficiency and managing skills. In an attempt to keep in line with developments in psychology and cognitive science, this upsurge in language education research has investigated the impact of language teachers' various cognitive, affective and personality characteristics on their teaching practices and professional success. Among those investigated, one can refer to EFL teachers' multiple intelligences (Pishghadam \& Moafian, 2007), emotional intelligence (Hashemi, 2008), and self-efficacy (Moafian \& Ghanizadeh, 2009). Following this line of research, another viable domain in which to investigate the concept of teacher success in foreign and second language teaching programs is L2 teachers' critical thinking ability.

In an ever-changing world where almost nothing can be taken on faith for long, 'critical thinking' seems to be a solution. Defined as the ability to discipline and control thinking to process information more easily, effectively and efficiently (Paul, 1990; cited in Longman, Atkinson \& Breeden, 1997), critical thinking is critical for students to perform well not only in educational systems, but also in future workplaces, and social and interpersonal contexts. Students must go beyond absorbing knowledge and learn to heighten skills to judge information, evaluate alternative evidence and argue with tenable reasons $(\mathrm{Ku}, 2009)$. Hence, educators need to place a premium on enhancing thinking abilities in learners. Mainstream critical thinking research has focused on ways of developing this skill in learners (e.g., Dantas-Whitney, 2002; Faravani, 2006), and failed to investigate its application to teachers' success and the efficiency of teacher education programs. What seems to be obvious is that in order to prepare learners for ways of thinking that will be expected of them, teachers themselves need to be able to think in those terms. The questions of how teachable critical thinking is and to what extent current EFL/ESL teacher education programs implicitly or explicitly draw on the construct are yet to be answered. However, before addressing such questions, the chart-topping issue to be investigated is the extent to which EFL teachers with more advanced critical thinking capabilities are pedagogically successful. 


\section{Review of the Related Literature}

\subsection{Teacher Success}

The investigation of teacher success is important as with better knowledge of the concept, educators can better envisage professional development directions, and enhance the quality of teacher education programs. Teachers are change agents (Pettis, 2002). "They can be agents for change in a world in desperate need of change: change from competition to cooperation, from powerlessness to empowerment, from conflict to resolution, from prejudice to understanding" (Brown, 2001; p. 445). Sanders and Rivers (1996) consider teachers as the single most important factor affecting student achievement. Along the same line, King (2003) states that teaching is a complex activity that is influenced by the multitudinous facets of teacher quality and teacher quality is a crucial predictor of student performance.

These and countless other studies have verified the significance of teachers' role in the process of learning in general and language learning in particular. Hence, it is not surprising that upon browsing the related literature, numerous calibers of successful, effective and good teachers can be noted. While some of these measures place a premium on teachers' thinking skills, most of them have focused on cognitive, affective and personality traits put forth by mainstream L2 researchers. For one, Hashemi (2008) investigated the relationship between Iranian EFL teachers' emotional intelligence (EQ) and their professional success, but failed to find out any significant relationship between the two variables. As another example, Tamblyn (2000) has identified seven qualities of successful teachers, most of which focus on teachers' personality features and attitudes:

- subject competence;

- skill in motivating learners through positive reinforcement;

- flexibility and expertise in adapting the materials to the students' needs;

- willingness to take risks and make mistakes;

- respect for learners;

- warmth, a caring attitude, and a sense of humor;

- self-esteem, satisfaction with the profession, and a willingness to go the extra mile.

Following their interviews with teacher awardees in Hong Kong, Elizabeth, May and Chee (2008) propose a more panoramic perspective of successful teacher qualities. They identify three groups of features exerting influence on teacher success: personal qualities (e.g. caring for students, enthusiasm, self-reflection, attaching importance to moral education and having a positive influence on students' values and attitudes, and holding individual teaching beliefs), professional qualities (e.g. classroom management, and knowledge of the subject matter), and contextual features (e.g. personal context, school context, and context beyond school). This viewpoint of teacher success is more promising due to its inclusion of such facets of critical thinking as self-reflection and a concern with the context of teaching.

Elizabeth et al. (2008) also report the results of their meta-analysis of studies on teacher effectiveness, asserting that on top of distinctive personality traits, effective teachers are distinguished by strong cognitive skills:

They are subject specialists who are able to select, organize, and deliver content, are efficient and effective in the use of instructional time, and are able to vary their teaching strategies according to student needs... [They] are skilful in using questions, promote critical and creative thinking, and use wait time when seeking student response (p. 624).

As this definition indicates, the ability to promote critical thinking can be singled out as pivotal to teacher effectiveness, a quality that presupposes teachers' own capacity and willingness to think critically.

Taking a similar path, Korthagen (2004) has developed an interactive five-layer 'onion model' to capture "the essence of a good teacher"; moving from the outermost to the innermost, the layers are termed: Behavior, Competencies (knowledge, skills, and attitudes), Beliefs, Identity and Mission. Unlike common practice, Korthagen conceptualizes teacher effectiveness in terms of not only teachers' own characteristics, but also the influence of the whole ambience in which they operate, i.e. the five levels are susceptible to change under various circumstantial variables. It follows that educational systems can enhance good teacher characteristics as self-esteem, cooperation, and critical thinking by creating a nourishing environment.

\subsection{Critical Thinking}

\subsubsection{Definition}

An overwhelming number of definitions of critical thinking can be found in the literature, all culminating in Mizner' s famous sentence: "I respect faith, but doubt is what gets you an education." (cited in Vaughn, 2008). Paul (1985, p. 37) defines critical thinking as "learning how to ask and answer questions of analysis, synthesis 
and evaluation". In like manner, Brookfield (1987, p. 229) maintains that critical thinking involves two interrelated processes: "identifying and challenging assumptions, and imagining and exploring others." Pithers and Soden (2000) concur that critical thinking encompasses a number of abilities such as identifying a problem and the assumptions on which it is based, focusing the problem, analyzing, understanding and making use of inferences, inductive and deductive logic, and judging the validity and reliability of assumptions and sources of data. Siegel (1988) defines critical thinking as "the educational cognate of rationality", and a critical thinker as one who is "appropriately moved by reasons" (p. 32).

Following Paul (1990), Longman, Atkinson and Breeden (1997) use the acronym MIND, standing for the components of the critical thinking process (see Figure 1). They mention that a critical thinker may start at any point in the circle, but he will definitely cover all components.

Taking a more holistic view of critical thinking, $\mathrm{Ku}$ (2009) maintains the maturation of the conceptualization of critical thinking from a preoccupation with cognition to one which has both a cognitive and a dispositional aspect to it. Simply put, "besides the ability to engage in cognitive skills, a critical thinker must also have a strong intention to recognize the importance of good thinking and have the initiative to seek better judgment" (p. 71).

Upon contemplating these and other definitions of the concept, a number of traits characterizing a critical thinker surface. A critical thinker is one who among other features:

- has a strong intention to recognize the importance of good thinking;

- identifies problems and focuses on relevant topics and issues;

- distinguishes between valid and invalid inferences;

- suspends judgments and decisions in the absence sufficient evidence;

- understands the difference between logical reasoning and rationalizing;

- is aware of the fact that one's understanding is limited and that there are degrees of belief;

- differentiates between facts, opinions and assumptions;

- watches out for authoritarian influences and specious arguments;

- anticipates the consequences of alternative actions.

2.2.2. Critical thinking, language education, and language educators

One of the prevailing concepts in educational reform today is critical thinking. The significance of critical thinking in education and particularly higher education is now acknowledged by a large number of educators. Schafersman (1991) asserts that all education must involve not only 'what to think', but also 'how to think'. However, he regrets, most education has been preoccupied with transmitting and acquiring knowledge and facts, and the subtlety of the concept of critical thinking has obviated students' realization of its absence and educators' recognition of its significance all alike. But given the increasing number of disciplines, the vitality of learning and teaching techniques to acquire, understand and evaluate information surfaces.

Atkinson (1997) states that the concept of critical thinking has entered the field of language education from L1 and already made its mark. However, he is skeptical as to whether it can be taken on faith, and believes language educators should consider its applicability to the field carefully and cautiously. He states four reasons for this speculation:

Critical thinking may be more on the order of a non-overt social practice than a well-defined and teachable pedagogical set of behaviors; (b) critical thinking can be and has been criticized for its exclusive and reductive character; (c) teaching thinking to nonnative speakers may be fraught with cultural problems; and, (d) once having been taught, thinking skills do not appear to transfer effectively beyond their narrow contexts of instruction.(p. 71)

Atkinson's argument Davidson (1998) reciprocates by referring to what Siegel (1989) calls "self-reflective justificatory strategy" meaning that even to make a case against critical thinking, one has to presuppose its validity, i.e. to be a critical thinker. As far as the cultural load of critical thinking is concerned, Davidson (1998) cites Ennis (1996) as saying that the problem for educators is not whether critical thinking has value for people from non-Western cultures, but how and when critical thinking should be drawn upon. He continues:

Part of the English teacher's task is to prepare learners to interact with native speakers who value explicit comment, intelligent criticism, and intellectual assertion. Maybe even more than the L1teacher, we as L2 teachers have good reason to introduce higher level students to aspects of critical thinking. If we do not, our students may well flounder when they are confronted with necessity of thinking critically, especially in an academic setting.(p.121) 
However, Davidson concedes that in order to be usable in TESOL, critical thinking must be clearly defined and adapted culture-wise. In a pilot study using a critical thinking essay test, a treatment group of Japanese college students receiving supplemental instruction in critical thinking skills significantly outperformed a control group receiving only content-based, intensive academic English instruction (Davidson \& Dunham, 1997). The results seem to confirm that critical thinking can be taught to ESL/EFL students.

A point of caution is in order with regard to the confusion of critical thinking in TESOL and critical approaches to TESOL; Pennycook (1999) clearly recapitulates the point:

Critical thinking is generally an apolitical approach to developing a sort of questioning attitude in students; critical approaches to TESOL have to do with a political understanding of the location of pedagogy and the development of a method of teaching aimed at transformation (p.341).

Given the vast number of studies alluding to the teachability of critical thinking, the question is how a critical thinking-based education can be implemented and what qualifications and roles language teachers should assume in such a process.

Lin (1999) capitalizes on teachers' ability to think and teach critically, showing in her study that particular ways of teaching English in Hong Kong may induce the perpetuation or the transformation of class-based inequality. In like manner, Ruminski and Hanks (1995) believe instructors should have a clear concept of critical thinking before they embark on teaching and evaluation.

In a similar vein, Oster (1989) endorses the Western education system for its being open to a plurality of views, and encouraging originality and analysis, rather than memorization and quotation. He believes if students are to enter an American or European university, they must be taught to think in a way that will be expected of them, not to presume things to be universal when they are culture-bound, to feel free to express their thoughts and experiences and to find value in so doing. To these ends, he offers the study of the target language literature and its analysis as a safe and promising ground for developing critical thinking skills in foreign or second language learners.

Given what was said above regarding the growing salience of critical thinking and its observable ignorance by EFL teachers' success researchers, the present study was undertaken to see whether Iranian EFL teachers' success was significantly influenced by their ability to think critically.

\section{Methodology}

The present study was carried out to address the following research question and null hypothesis:

- Research Question

What is the relationship between Iranian EFL teachers' critical thinking ability and their professional success?

- Null Hypothesis

There is no significant relationship between Iranian EFL teachers' critical thinking ability and their professional success.

\subsection{Participants}

To answer the research question, 67 (49 female and 18 male) Iranian teachers of pre-intermediate and intermediate adult EFL learners from two language institutes in Iran took part in the study. Nineteen of the teachers held a Master's degree and the rest a Bachelor's mostly in English $(\mathrm{N}=56)$, and a small number of other disciplines, including Persian literature, management, IT, chemistry and biology $(\mathrm{N}=11)$. The teachers ranged in age from 21 to 36, and varied in their ELT experience from 6 months to 17 years. Furthermore, to obtain measures of these teachers' professional success, 881 male and female English language learners, the students of the teacher-participants at the time, ranging in age from 17 to 41, learning English at the above-mentioned institutes participated in the study. The number of students who provided such measures for each teacher ranged from 8 to 21 from one class or two classes.

\subsection{Instrumentation}

\subsubsection{Successful Iranian EFL Teacher Questionnaire (Moafian \&Pishghadam, 2009)}

To obtain measures of teacher success through student evaluation, a 47-item questionnaire on characteristics of successful Iranian EFL teachers, developed on the basis of the elicited comments and opinions of EFL teachers and learners and also existing teacher success questionnaires, was utilized. Each item is followed by a 5-point Likert Scale, ranging from 'strongly agree' to 'strongly disagree'. As for the construct validity of the instrument, Moafian and Pishghadam (2009) conducted a factor analysis. The interfactor correlation matrix of their analysis 
revealed correlations of 0.25 or greater suggesting that a varimax rotation would appropriately represent the underlying factor structure. Principle axis factoring extracted 12 factors with eigenvalues greater than 1.0 which accounted for $48 \%$ of the variance. Variable communalities were all greater than 0.30 . The 12 factors extracted were termed: accountability, interpersonal relationships, attention to all, examination, commitment, learning boosters, creating a sense of competence, teaching boosters, physical and emotional acceptance, empathy, class attendance and dynamism. The results of reliability analysis exhibited that the total reliability of the questionnaire is very high $($ Cronbach' alpha $=.94)$. The item-total correlations were also assessed for all items, ranging from .40 to .62. Correlations were therefore within the acceptable range of 0.30 or greater (Wintergerst, DeCapua \& Itzen, 2001; cited in Moafian \& Pishghadam, 2009). The scores were reported in percentages.

\subsubsection{Watson-Glaser Critical Thinking Appraisal-Form A (Watson \&Glaser, 1980)}

The Watson-Glaser critical Thinking Appraisal comprises five subsections which practically measure the five aspects of critical thinking as defined by Watson and Glaser (1980):

- Drawing inferences based on factual statements;

- Recognition of assumptions in a number of assertive statements;

- Making deductions: To determine if conclusions follow from information in given statements;

- Interpreting evidence to decide if conclusions are legitimate or not;

- Evaluating arguments as being strong or weak;

The appraisal from consists of general scenarios along with 16 items for each aspect of the construct and is not subject-related (Watson \& Glaser, 1980). It includes 80 items each followed by two to five alternatives, which can be completed in 60 minutes. In addition to the face, content, construct, and criterion validity of the appraisal, its test-retest reliability has been shown $(r=0.81)$ by Watson and Glaser (1980). The researcher used the Farsi version of the appraisal, translated by Faravani (2006), of which the reported reliability is $85 \%$ (Cronbach's $\alpha=0.85$ ). Scoring is facilitated through the availability of an answer key, yielding a composite score for the five subsections of the appraisal from 0 to 80 .

\subsubsection{Procedure}

To obtain measures of teachers' critical thinking ability, an ex post facto design was employed. The teachers were given the Watson-Glaser Critical Thinking Appraisal-Form A (WGCTA-FA) to fill out in their free time. Each was shortly introduced to the purpose of the research and provided with some brief oral instruction on how to complete the appraisal form. Moreover, their professional success was evaluated toward the end of the term as their students filled out the Successful Iranian EFL Teacher (SIET) questionnaire in their regular class time. Having collected the data, the researcher set off on data analysis to answer the research question as to whether EFL teachers' critical thinking ability can be a predictor of their student-evaluated professional success.

\subsubsection{Data analysis}

The data were analyzed through the $16^{\text {th }}$ version of the Statistical Package for Social Sciences (SPSS). The first step was to find out whether the participants' SIET scores showed a significant correlation with their total WGCTA-FA scores. As two continuous variables were involved, the Pearson product-moment correlation coefficient for the two sets of scores was calculated. Given the significant correlation obtained, the next step was to run multiple regression analysis with the five aspects of critical thinking underlying WGCTA-Form A as the set of independent variables and the obtained SIET scores as the dependent variable.

\section{Results}

The table of descriptive statistics (Table 1) indicates that all the 67 teacher-participants who filled out the WGCTA-FA and were evaluated through IESTQ were included in the data analysis procedure as active valid cases. The participants' scores ranged from 13 to 75 on WGCTA-FA and from 30 to 94 on SIETQ.

From a statistical perspective, the assumption behind the null hypothesis is that there is no significant correlation between Iranian EFL teachers' critical thinking ability and their professional success. To test this hypothesis, Pearson product moment correlation was run. Table 2 depicts the coefficient of this correlation between total WGCTA and SIET scores. The calculated correlation coefficient is 0.719 which is significant at 0.01 level of significance $(r=0.719, p \leq 0.01)$. In other words, the two variables at issue are significantly positively correlated with each other and the null hypothesis is, by a wide margin, rejected. This finding is better envisaged in Graph 1 which provides a visual representation of the correlation, plotting WGCTA scores on SIET scores.

Having rejected the null hypothesis and substantiating a significant correlation between teachers' student-evaluated success and their critical thinking ability, the next step in the data analysis was to determine 
where the correlation lay in terms of the five aspects of critical thinking as defined by Watson \& Glaser (1980) (see Section 3.2.2).

Given the teacher-participants' scores on the five aspects of critical thinking as the set of independent variables and their scores on SIETQ as the dependent variable, a multiple regression analysis was conducted. Table 3 serves to confirm the result of the Pearson product moment correlation analysis presented earlier in this section. The correlation coefficient between the set of independent variables, namely measures of the five aspects of critical thinking, and the dependent variable, namely measures of the participants' professional success, has an approximate value of 0.7 which, as the table of ANOVA (Table 4) indicates, is statistically significant, thus the rejection of the null hypothesis. Moreover, the $\mathrm{R}$ Square, as "the percentage of the variance of the predicted (dependent) variable that is due to, or explained by, the combined predictor (independent) variables" (Best \& Kahn, 2006, pp.432-433), has a value of 0.537. It means that about $53 \%$ of the variance of the teacher-participants' SIET scores is explained by their total scores on WGCTA-FA.

Table 5 provides an indication of the extent to which each of the five components of critical thinking has significance for EFL teachers' professional success. As indicated in the table of partial correlations, when excluding the combined correlation of the five independent variables with the dependent variable, only two of the components of critical thinking, namely 'drawing inferences' and 'interpreting evidence' show significant correlation at 0.05 level of significance (Beta $=0.224, p \leq 0.05$ for 'drawing inferences' and Beta $=0.357, p \leq$ 0.01 for 'interpreting evidence'), and for the last component, i.e. 'evaluating arguments', a trend toward statistical significance is observable (Beta $=0.192, p \leq 0.06$ ). However, these correlation coefficients are lower than 0.4 and therefore low (Best \& Kahn, 2006). This may suggest that it is the combined effect of the components of critical thinking that has significance in terms of EFL teachers' professional success.

In order to determine to what extent these three aspects of critical thinking, namely 'drawing inferences', 'interpreting evidence' and 'evaluating arguments' correlate with the dependent variable, another multiple regression analysis was conducted using the 'stepwise' entry system. Table 6 presents the output of this analysis.

As can be seen in the table, 'interpreting evidence' was first entered into the model of analysis, based upon which $41.4 \%$ of the SIET score can be accounted for $\left(\mathrm{R}=0.643, \mathrm{R}^{2}=0.414\right)$. However when paired together, 'Interpreting evidence' and 'Drawing inferences' show a relatively higher correlation with the dependent variable $(\mathrm{R}=0.694)$, and also the predictability of the SIET reading score rises to $48.1 \%$. In a similar vein, when the effect of the third component, 'Evaluating arguments', is included, the correlation coefficient goes up to 0.723 , and the predictability of the dependent variable equals $52.3 \%$. In addition, the analysis of variance indicates that the F observed is significant for all the three correlations above (Sig.= 0.00 ), and all the three models are then valid.

\section{Discussion}

As stated earlier, the present study intended to investigate if there is any relationship between Iranian EFL teachers' critical thinking ability and their pedagogical success. The results revealed that there is a significant positive relationship between the two variables in question. The size of this correlation indicates that generally high levels of critical thinking are related to high levels of teacher success as evaluated by EFL learners. This is hardly surprising since teachers' critical thinking ability, as its various definitions denote, can be said to influence nearly all their pedagogical decisions regarding how to group learners, how best to enhance learner motivation and self-esteem, what additional materials and tasks to draw upon, and numerous other 'how's, 'what's and 'why's.

It was also found that despite the relatively high correlation between total WGCTA and SIET scores, only three of the five components of critical thinking, namely 'interpreting evidence', 'drawing inferences' and 'evaluating arguments' correlate significantly with SIET scores. It needs to be mentioned that this conclusion should be made cautiously because of the ever-present threat of post hoc fallacy in correlational studies. In other words, the observed correlation does not necessarily amount to a cause-effect relationship; nor does failing to substantiate a significant correlation between two of the components of critical thinking, namely 'recognition of assumptions' and 'making deductions', and EFL teacher success measures leave out the possibility of causality between the variables at issue (Dornyie, 2007). To compound the problem, the three correlation coefficients are low when standing on their own, and only when the three components of critical thinking aregrouped together do they result in a high correlation coefficient( $\mathrm{r}$ ) of 0.7 . This finding might be attributed to the idiosyncratic composition of the group of participants, or the nature of the teacher success questionnaire. More research is required to confirm or disconfirm this finding with other more varied groups of EFL teachers or other 'EFL teacher success' measures.

\section{Conclusions and Implications}

EFL/ESL research on the prevailing concept of critical thinking has for the most part rotated around enhancing learning and skills development. In an attempt to extend this line of research to EFL teacher effectiveness and 
teacher education studies, the present researcher addressed the question of whether the critical thinking ability of Iranian EFL teachers of adults has any significance for their student-evaluated professional success. To this end, the five-component model of critical thinking as defined by Watson \& Glaser (1980) served as the basis of analysis. The statistical analysis procedures utilized substantiated a rather high significant positive correlation between the teacher-participants' total critical thinking scores on WGCTA-FA and their professional success measures on SIETQ $(\mathrm{r} \approx 0.7)$, thus the rejection of the null hypothesis. Further analysis indicated that this correlation coefficient was the combined effect of three of the five components of the critical thinking model used in this study: interpreting evidence, drawing inferences and evaluating arguments. It can be said that better critical thinkers turned out to be better EFL teachers. Having this point in mind, the results have some important implications in terms of the conceptualization of EFL/ESL teacher effectiveness, available teacher success measures, and EFL/ESL teacher education programs.

Having long been hailed as a salient aspect of scientific thinking and taken to extremes by positivists, the ability to think critically was in this study applied to a more flexible, but less clearly intelligible, domain of human knowledge, the study of language, more specifically the study of language teachers' professional success. Prior to the quest for developing communicative competence in language learners, a good language teacher was best conceived of as one who was there to simply impart knowledge of the target language onto the minds of learners, a hypothetical 'jar' of information to fill out empty 'mugs'(Richards \& Rodgers, 2001).

This conceptualization underwent a major breakthrough with the more demanding burden language teachers had to bear within a communicative language teaching (CLT) framework, placing a premium on the dynamics of the classroom and sweeping away from pre-set methods. The just-mentioned paradigm shift is best articulated by Brown (2000) who contends that nowadays "language teaching is not easily categorized into methods and trends; instead each teacher is called on to develop a sound approach to various language classrooms" (p.14). Such a perspective of language teaching resonates with a view of language teachers as critical thinkers, as ones who are not caught up in the ever swinging pendulum of pre-packaged ideas of others. To develop one's unique approach and work out what is likely to thrive in a particular setting, critical thinking should be at work. This might involve:

- drawing inferences and considering the possible short-term and long-term consequences of taking alternative actions;

- taking advantage of, interpreting and contemplating all available past and present evidence, including research evidence, other teachers' experiences, and information obtained through dynamic and alternative assessment; - evaluating others' postulated theories and arguments, carefully pondering their merits and demerits as well as their suitability to their unique teaching ambience;

- considering the validity of others' conclusions regarding the effectiveness and ineffectiveness of certain practices, approaches, and materials, hesitating to take their applicability on faith in the absence of conclusive evidence and before uncovering their underlying cultural, social and political assumptions.

Such demands indicate that critical thinking is inextricably tied to reflective teaching and action research, and the multitudinous number of studies which have testified to the significance of reflective teaching and action research in EFL/ESL confirm the observed significant correlation between critical thinking and EFL teacher success. It follows that the results of the study can also pay off in terms of teacher evaluation and teacher education programs.

To the researcher's best knowledge, no teacher evaluation instruments, particularly questionnaires, have explicitly incorporated critical thinking and its components as one of the main facets teachers' pedagogical success (e.g. see Feldman, 1996; Gadzella, 1971; Lowman, 1996; Saroyan and Snell, 1997; Shane, 1965). They might include some items which implicitly tap into the critical thinking ability of teachers. For example, in the Successful Iranian EFL Teacher Questionnaire used in the present study, there are a few items which address critical thinkking among which the following three stand out:

- $\mathrm{S} /$ he accepts constructive criticisms.

- $\mathrm{S} /$ he respects different ideas.

- $\mathrm{S} /$ he divides the class time appropriately for the different language skills according to the purposes of the course.

However, these items do not provide an exact operational definition of critical thinking. Given the observed significant correlation, this lacuna needs to be addressed by developers of EFL teacher success instruments. Moreover, EFL teacher educators are likely to enhance the efficiency of their courses by allocating some space in the topics and areas to be covered to familiarizing would-be teachers with the concept and its significance, and some tasks and activities to help them further their ability to think critically. 
At this point, a word regarding the limitations and delimitations of the study is worth mentioning. First and foremost, there is the problem of having the students as the only source for providing information concerning the teacher-participants' professional success. As Williams and Burden (1997) state, student evaluations of teacher effectiveness are influenced by a number of factors including teacher characteristics, class content, timing of the evaluation, and above all individual differences in student evaluators. The researcher believes that the evaluations would have been more reliable if it were possible to triangulate the data through other sources such as the professional judgement of supervisors or information on the learners' longitudinal success. A second point is that there were two groups of teachers from two different institutes, whose academic backgrounds, teacher education courses they had gone through, and various lengths of ELT experience might have influenced their scores on WGCTA. Needless to say, the definition of critical thinking as put forth by Watson \& Glaser (1980) is by no means the best one that exists, but given the availability of WGCTA-FA to the researcher, she based the statistical analyses on that definition.

In the face of the dearth of research on critical thinking as concerns language teachers' effectiveness, there is need for further research to:

- determine how best to incorporate 'critical thinking' as an aspect of EFL teacher education programs, and what tasks and activities would best enhance the ability to draw inferences, evaluate arguments and interpret evidence;

- devise teacher success questionnaires which include an operational definition of 'critical thinking' as one of their underlying aspects of the construct;

- find out to what extent EFL teachers' critical thinking ability matters for learners' success of different age groups and language proficiency levels.

\section{References}

Atkinson, D. (1997). A critical approach to critical thinking in TESOL. TESOL Quarterly, 31 (1): 79-95.

Best J.W. \& Kahn J.V. (2006). Research in education ( $3^{\text {rd }}$ ed.). USA: Pearson Education Inc.

Brookfield, S. (1987). Developing critical thinkers. Milton Keyes: Open University Press.

Brown, H.D. (2000). Principles of language learning and teaching (4 $\left.{ }^{\text {th }} \mathrm{ed}.\right)$. New York: Addison Wesley Longman, Inc.

Brown, H. D. (2001). Teaching by principles: An interactive approach to language Pedagogy (2 ${ }^{\text {nd }}$ ed). San Francisco: Longman.

Dantas-Whitney, M. (2002). Critical reflection in the second language classroom through audiotaped journals. System, 30: 543-555.

Davidson, B.W. (1998). A case for critical thinking in the English language classroom. TESOL quarterly, 32 (1): 119-123.

Davidson, B., \& Dunham, R. (1997). Assessing EFL student progress in critical thinking with the Ennis-Weir Critical Thinking Essay Test. JALT Journal, 19: 43-57.

Dornyei, Z. (2007). Research methods in applied linguistics. Oxford: Oxford University Press.

Elizabeth, C. L., May, C.M., \& Chee, P.K. (2008). Building a model to define the concept of teacher success in Hong Kong. Teaching and Teacher Education, 24: 623-634.

Faravani (2006). Portfolio and critical thinking. Unpublished M.A. Thesis. Iran: Ferdowsi University.

Feldman, K. A. (1996). Identifying exemplary teaching: Using data from course and teacher evaluations. New Directions for Teaching and Learning, 65: 41-50.

Gadzella, B. M. (1971). College students' views and ratings of an ideal professor, In I. J. Lehmann \& W. A. Mehrens (Eds.), Educational research readings in focus, pp. 131-138. New York: Holt, Rinehart and Winston.

Grosser, M.M. \& Lombard, B.J.J. (2008). The relationship between culture and the development of critical thinking abilities of prospective teachers. Teaching and Teacher Education, 24 : 1364-1375.

Hargreaves, A., \& Fullan, M. G. (1992). Understanding teacher development. New York: Teacher College Press. Hashemi, M. (2008). On the role of teachers' emotional intelligence on their pedagogical success. Unpublished M.A. Thesis. Tehran: Allame Tabataba'I University.

King R., J. (2003). Teacher quality: Understanding the effectiveness of teacher attributes. Retrieved June 21, 2007 from: http://www.epinet.org/content.cfm/books_teacher_quality_execsum_intro

Kuhn, D. (2005). Education for thinking. Cambridge: Harvard University Press. 
Korthagen, F. A. J. (2004). In search of the essence of a good teacher: towards a more holistic approach in teacher education. Teaching and Teacher Education, 20: 77-97.

$\mathrm{Ku}$, Y. L. K. (2009). Assessing students' critical thinking performance: Urging for measurements using multi-response format. Thinking Skills and Creativity, 4: 70-76.

Lin, A.M.Y. (1999). Doing-English-Lessons in the reproduction or transformation of social worlds? TESOL Quarterly, 33 (3): 393-413

Longman, D.G., Atkinson, R.H., \&Breeden, J.A. (1997). Strategic thinking and reading. Boston: Heinle \& Heinle Publishers.

Lowman, J. (1996). Characteristics of exemplary teachers. New Direction for Teaching and Learning, 65: 33-40.

Moafian, F., Ghanizadeh, A. (2009). The relationship between Iranian EFL teachers' emotional intelligence and their self-efficacy in Language Institutes, System, doi:10.1016/j.system.2009.09.014

Moafian, F., \& Pishghadam, R. (in press). Construct validation of a questionnaire on characteristics of Successful Iranian EFL teachers. Pazhuhesh-e Zabanha-ye Khareji.

Oster, J. (1989). Seeing with different eyes: Another view of literature in the ESL class. TESOL Quarterly, 23(1): 85-103.

Paul, R. W. (1985). Bloom's taxonomy and critical thinking intervention. Educational Leadership, 42(8): 36-39.

Pennycook, A. (1999). Introduction: Critical approaches to TESOL. TESOL Quarterly, 33: 329-348.

Pettis, J. (2002). Developing our professional competence: Some reflections, In J. C. Richards, \& W. A. Renandya (Eds.), Methodology in language teaching: An anthology of current practice (pp. 393-396). Cambridge: Cambridge University Press.

Pishghadam R. \& Moafian F. (2007). The ole of high school teachers' multiple intelligences in their teaching success. Foreign Languages Research Quarterly, 42: 22-35.

Pithers, R. T., \& Soden, R. (2000). Critical thinking in education: A review. Educational Research, 42: $237-249$.

Richards, J.C. \& Rodgers, T.S. (2001). Approaches and methods in language teaching ( $2^{\text {nd }}$ ed.). Cambridge: Cambridge University Press.

Ruminski, H. J., \& Hanks, W. E. (1995). Critical thinking lacks definition and uniform evaluation criteria. Journalism and Mass Education Educator, 50(3): 4-11.

Sanders, W., \& Rivers, j. (1996). Cumulative and residual effects of teachers on future student academic achievement. Retrieved Dec. 28, 2009 from: http://mdk 12.org/practices/ensure/tva/tva_2.html.

Saroyan, A. \& Snell, L. S. (1997). Variation in lecturing styles. Higher Education, 33 (1): 85-104.

Schafersman (1991). An introduction to critical thinking. Retrieved January 1, 2010 from: www.freeenquiry/criticalthinking.html

Shane, H. G. (1965). How do they rate you professor? NEA Journal, LIX (8): 18-20.

Siegel, H. (1988). Educating reason: Rationality, critical thinking, and education. New York: Routledge.

Suwandee, A. (1995). Students' perceptions of university instructors' effective teaching characteristics. SLLT Journal, 5: 6-22.

Tamblyn, P. (2000). Qualities of success: Lessons from a teacher career. Education Canada, 40(1): 16-19.

Vaughn, L. (2008). The power of critical thinking: Effective reasoning about ordinary and extraordinary claims $\left(2^{\text {nd }}\right.$ ed.). Oxford: Oxford University Press.

Watson, G., \& Glaser, E. (1980). Watson- Glaser critical thinking appraisal. England: The Psychological Corporation.

Williams, M. \& burden, R.L. (1997). Psychology for language teachers: A social constructivist approach. Cambridge: Cambridge University Press. 
Table 1. Descriptive statistics

\begin{tabular}{|l|l|l|l|l|l|l|l|}
\hline & $\mathrm{N}$ & Range & Minimum & Maximum & Mean & Std. Deviation & Variance \\
\hline WGCTA & 67 & 62.00 & 13.00 & 75.00 & 49.37 & 14.02 & 196.66 \\
SIET & 67 & 64.00 & 30.00 & 94.00 & 62.38 & 15.30 & 234.21 \\
Valid N (listwise) & 67 & & & & & & \\
\hline
\end{tabular}

Table 2. Pearson correlation coefficient

\begin{tabular}{|ll|l|l|}
\hline & WGCTA & IETS \\
\hline WGCTA & $\begin{array}{l}\text { Pearson Correlation } \\
\text { Sig. (2-tailed) }\end{array}$ & 1 & $\begin{array}{l}.719\left(^{* *}\right) \\
.000\end{array}$ \\
& N & 67 & 67 \\
\hline SIET & Pearson Correlation & $.719\left(^{* *}\right)$ & 1 \\
& Sig. (2-tailed) & .000 & \\
& N & 67 & 67 \\
\hline
\end{tabular}

** Correlation is significant at the 0.01 level (2-tailed).

Table 3. Model summary

\begin{tabular}{|l|l|l|l|l|}
\hline Model & R & R Square & Adjusted R Square & Std. Error of the Estimate \\
\hline 1 & $.733^{\mathrm{a}}$ & .537 & .499 & 10.82727 \\
\hline
\end{tabular}

Table 4. ANOVAb

\begin{tabular}{|ll|l|l|l|l|l|}
\hline Model & Sum of Squares & df & Mean Square & F & Sig. \\
\hline $1 \quad$ Regression & 8306.893 & 5 & 1661.379 & 14.172 & $.000^{\mathrm{a}}$ \\
\cline { 2 - 4 } & 7151.018 & 61 & 117.230 & & \\
\multicolumn{1}{|c|}{ Total } & 15457.910 & 66 & & & \\
\hline
\end{tabular}

a. Predictors: (Constant), Evaluating arguments, Recognition of assumptions, Drawing inferences, Making deductions, Interpreting evidence

b. Dependent variable: SIET scores

Table 5. Coefficients of partial correlations

\begin{tabular}{|l|l|l|l|l|l|}
\hline \multirow{2}{*}{ Model } & \multicolumn{2}{|l|}{ Unstandardized Coefficients } & Standardized Coefficients & & \\
\cline { 2 - 6 } & $\mathrm{B}$ & Std. Error & Beta & $\mathrm{t}$ & \multicolumn{1}{|l|}{ Sig. } \\
\hline 1 (Constant) & 24.398 & 4.977 & & 4.903 & .000 \\
Drawing inferences & .910 & .424 & .224 & 2.147 & .036 \\
Recognition of Assumptions & .263 & .468 & .061 & .561 & .577 \\
Making Deductions & .531 & .478 & .125 & 1.111 & .271 \\
Interpreting Evidence & 1.440 & .479 & .357 & 3.006 & .004 \\
Evaluating Arguments & .688 & .357 & .192 & 1.931 .058 \\
\hline
\end{tabular}

Table 6. Model summary

\begin{tabular}{|l|l|l|l|l|}
\hline Model & R & R Square & Adjusted R Square & $\begin{array}{l}\text { Std. Error of the } \\
\text { Estimate }\end{array}$ \\
\hline 1 & $.643^{\mathrm{a}}$ & .414 & .405 & 11.80770 \\
2 & $.694^{\mathrm{b}}$ & .481 & .465 & 11.19264 \\
3 & $.723^{\mathrm{c}}$ & .523 & .501 & 10.81520 \\
\hline
\end{tabular}

a. Predictors: (Constant), Interpreting evidence

b. Predictors: (Constant), Interpreting evidence, Drawing inferences

c. Predictors: (Constant), Interpreting evidence, drawing inferences 


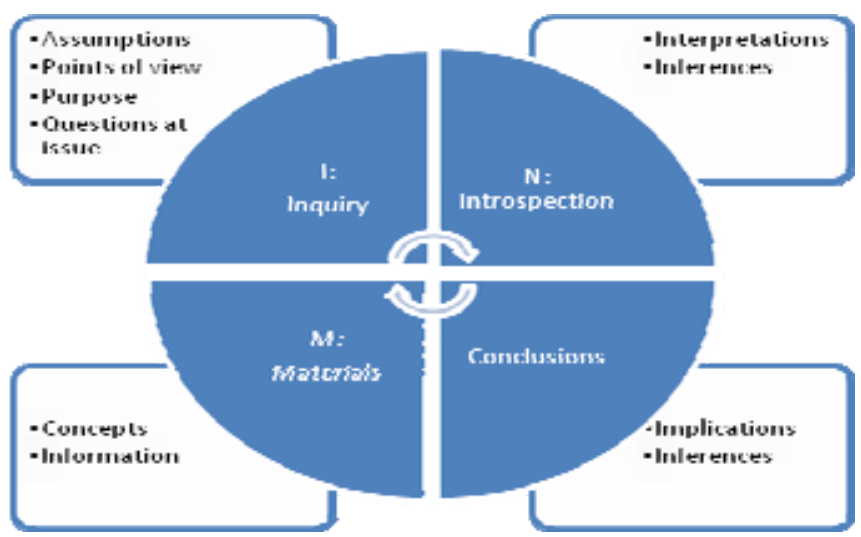

Figure 1. MIND Components adapted from Atkinson et al. (2008)

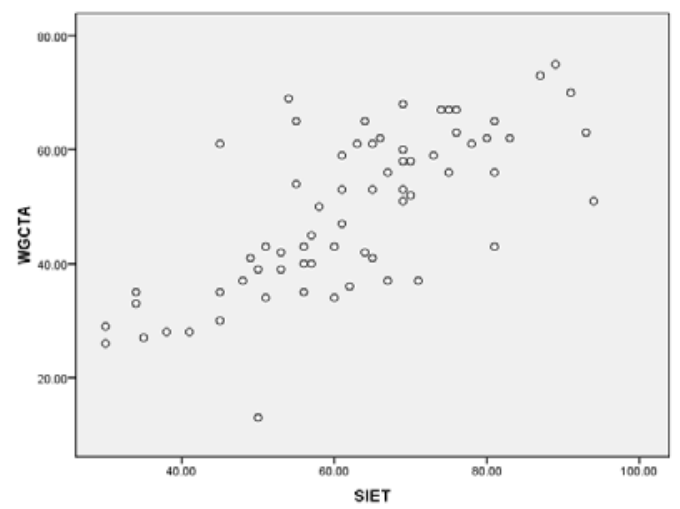

Graph 1. Scattergram of the correlation of WGCTA-FA and SIET scores 